丧 3 人工海水中のカド々ウムの定量

\begin{tabular}{|c|c|c|c|c|c|}
\hline No. & 余水吾 & $\begin{array}{c}\text { 棌加量 } \\
\text { (mg) }\end{array}$ & $\begin{array}{c}\text { カドミウ } \\
\text { 厶添加量 } \\
(\mu \mathrm{g})\end{array}$ & $\begin{array}{c}\text { カドミウ } \\
\text { ム分析値 } \\
(\mu \mathrm{g})\end{array}$ & $\begin{array}{c}\text { 回取率 } \\
(\%)\end{array}$ \\
\hline 1a) & 0.5 & 20 & 20 & 19.3 & 96.5 \\
\hline $2^{6)}$ & 0.5 & 10 & 8 & 7.0 & 87.5 \\
\hline $3^{a)}$ & 1 & 10 & 20 & 18.8 & 93.7 \\
\hline $4^{(a)}$ & 1 & 10 & 50 & 20.4 & 40.8 \\
\hline 5 & 5 . & 10 & 20 & 21.0 & 100.5 \\
\hline 6 & 1 & 10 & 10 & 9.05 & 90.5 \\
\hline 7 & 1 & 10 & 10 & 9.5 & 95.0 \\
\hline
\end{tabular}

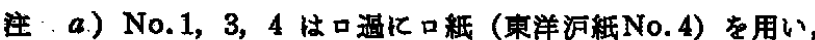

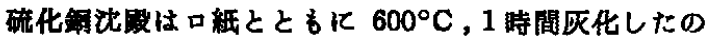
ち, 王水に谘解した。 No. 4 ではルツボに兏化の際 CuO が酤着して溶解不完全となった。

b) 人工海水に微成分として Co $100 \mu \mathrm{g}$, Ni $100 \mu \mathrm{g}$, Zn $200 \mu \mathrm{g}$ 渿加しだ。

加文，以後海水の睾合に準じてカドミウムを定量する。

\section{4 海水，海産生物のカドミウム含是}

前項の定量法にしたがって海水，海産生物中のカドミウム量を 求めた。試料には, 近海表面海水 3 個, 海産動物 3 個, 海産植物 2 個を用い，海夝生物との比較の目的で陸水生物 2 個についてむ カドミウム含量を求めた。

\section{表 4 海水のカドミウム量 試、料海水}

大阪府浜寺海湈; Sept. 15, 1960 探取; pH 8.4, $d: 1.020, \mathrm{Cl}: 10.74 \%$ 大陵府寺海岸; Oct. 25, 1960 採取; pH 8.3, $d: 1.024, \mathrm{Cl}: 14.09 \%$ 和歌山県白浜田辺湾; Nov. 28, 1960 探取; p] 8. 8.4, $d: 1.025, \mathrm{Cl}: 18.08 \%$ 。
カドミウム量 $(\mu g / l)$

0.08

0.17 s
生物試料は屈乾したのち $500^{\circ} \sim 550^{\circ} \mathrm{C}$ の温度で電気炉を用い て灰化した。兏分はいずれも風乾体に対して $10 \%$ 内外であった。 分析結果を表 4 〜 6 に示す。

表 5 貝類（肉部）のカドミウム量

$$
\text { 試料カドミウム最 }(\%)
$$

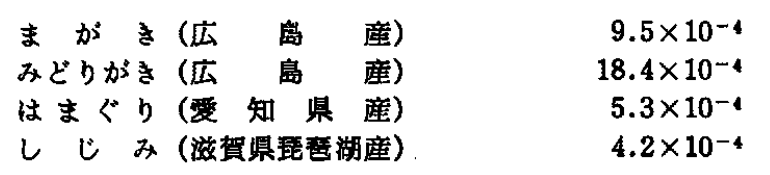

表 6 藻類のカドミウム量

武料北卡方么量(\%)

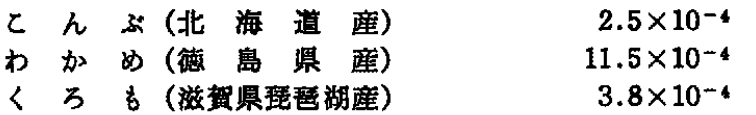

表 4 に見られるように海水試料のカドミウム含量は $0.08 〜 0.17$ $\mu \mathrm{g} / l$ で, 約 $0.1 \mu \mathrm{g} / l$ と考えられる。この值は Riley らの值 $0.024 \sim 0.25 \mu \mathrm{g} / l$ ならびに Buljan, 著者らの推定值に比較的 近く, $0.1 \mu \mathrm{g} / l$ 海水中のカドミウム量として妥当な值と考え られる。

がきははまぐり（貝殸を除いた肉の部分）およびこんぶ，わか めの灰分のカドミウム含量はいずれも $10^{-4 \%}$ で，ての量はきわ めて小さい。比較に用いた陸水生物との間にはカドミウム含量に いちじるしい差は認められなかった。

本研究の一部は文部省科学研究費（総合）によっておとなっで ものであるととを付記します。

(1961 年 4 月, 日本化学会第 14 年会講演)

Nーベンソイルフェニルヒドロキシルアミンによるプロトアクチニゥム-233 の共沈分離*1

（眧和 36 年 10 月 18 日受理）

鈴 木 信 男十・工 藤洌十

共沈法によるプロトアクチニウム-233の無担体分雄について検討した。ブロトアクチニウムはトリウムを原子炉で照射し，二

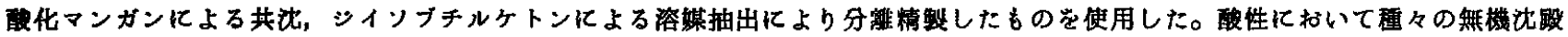
へのプロトアクチニウムの共沈范検討した結果，後处理の簡単なものでは二酸化マンガンを除き共沈率はきわめて悪く，トリウム からのプロトアクチニゥムの分噰法として不適当であった。そとで有機試薬を沈殿剂に用いた場合のプロトアクチニウムの共沈に

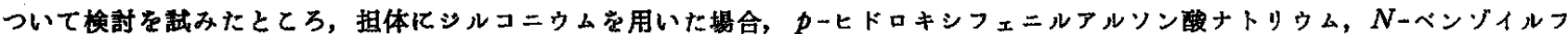
エニルヒドロキシルアミンが高仅章でプロトアクチニウムを捕集するてとが判明しだ。後処理の簡単な $N$ ーベンゾイルフェニルヒ

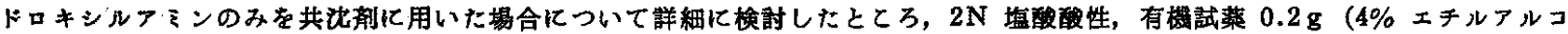

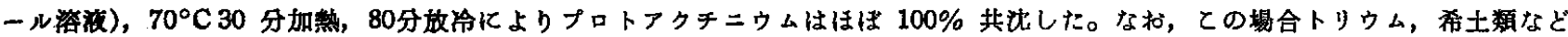
は共沈しない。との方法によってトリウムから故射化学的に純粋なプロトアクチニウム-233 高収率で無担体分離できた。

\section{1 緒}

トリウムの中性子照射によって大量にえられるようになったプ ロトアクチニウム-233 はウラン-233 の原料として近年特に注目

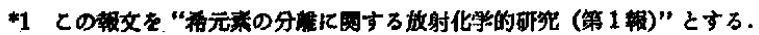

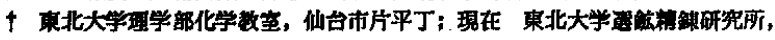
仙台宙影

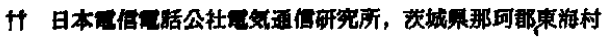

されてきている。また,ブロトアクチニウム-231 は化学探鉱上 からも興味がもたれている。しかし，プロトアクチニウム住化学 的挙動が複雑なため，その取り报いは困難であり，再現性のある 結果はえにくいといわれている1。

プロトアクチニウムの分踓法としては二酸化マンガン，過酸化

1) J. J. Katz, G. T. Seaborg, "The Chemistry of the Actinide Elements" p. 67 (1957) Metheren \& Co. Ltd. London. 
鉛, 酸化スズ, フッ化ジルコン酸バリウムによる共沈法2) 5), シ イソブチルケトンの, ジイソブチルカルビノール73)などによる溶 媒抽出泣:(9) (1)，イオン交撸法12)など多数の方法13がもらいられて いる。二酸化マンガンによる共沈法はウラン鋔中のプロトアクチ

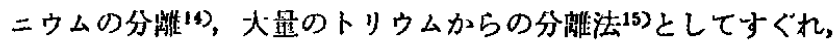
古くから広くもちいられている。最近，有機共沈法が話題になっ てきており(1) 21)，マンデル酸 ジルコニウムによるウラン鉱中の プロトアクチニウムの迅速定量法が報告されている22》。著者らは トリウムの中性子照射により生じたプロトアクチニウムの共沈分 離について検討し，沈殿绪として $N$-ベンゾイルフェニルヒドロ キシルアミンをもちいることにより，良好な結果がえられたので 報告する。

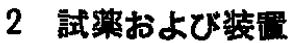

\section{1 試 菓}

2.1.1 プロトアクチニウム-233 溶液：本実験でもちいたブロ トアクチニウム-233 は 3.1 で述べる方法により分離精製したも のをもちいた。

2.1.2一般試菜: 酸，アルカリおよび担体などにもちいた無幾 試染類は特級品をそのまま便用した。有機沈殿绪としてもちいた $N$-ベンゾィルフェニルヒドロキシルアミンなどの有機試薬は東 京化成の製品をそのまをもちいた。エチルアルコールは 2 回蒸留 したものを，他の有機溶媒は特級品をそのまま使用した。

\section{2 放射能湘定测烈}

放射能測定には神戸工業製のウエル型シングルチャンネル $\gamma$ 線 スペクトロメーターをもちいた。なお，試料はポリエチレン製の 放射能測定管(山一式放射能測定ビンNo.1) に入れ測定した。

\section{3 実験および結果}

\section{1 プロトアクチニウム -233 溶洨の譆製}

プロトアクチニウム-233 のトレーサー溶液は従来の共沈，抽

2) L. I. Katzin, R. W. Stoughton, J. Inorg. Nucl. Chem. 3, 229 (1956).

3) C. A. Goodall, R. L. Moore, ibid. 11, 290 (1959).

4) G. C. Bate, J. R. Huizenga, H. A. Potratz, Geochim. et Cosmo. chim. Acta 16, 88 (1959)

5) G. T. Seaborg, J. J. Katz, "The Actinide Elements" p. 103 (1954) McGr.

6) A. Goble, J. Golden, A. G. Maddock, Can. J. Chem. 34, 284 (1956).

7) F. L. Moore, S. A. Reynolds, Anal. Chem. 29, 1596 (1957).

8) K. A. Kraus, Q. van Winkle, TID-5223, p. 296 (1952)

9) E. K. Hyde, M. J. Wolf, TID-5223, p. 197 (1952).

10) J. R. Oliver, J. R. Meriwether, R. H. Rainey, ORNL-2668 (1959).

11) F. L. Moore, Anal. Chem. 28, 1596, 1660 (1957).

12) K. A. Kraus, G. E. Moore, F. Nelson, J. Am. Chem. Soc. 70 , 2692 (1956).

13) M. Lederer, Anal. Chim. Acta I, 134 (1953).

14) K. A. Krans, Q. van Winkle, TID-5223, p. 259 (1952).

15) L. I. Katzin, R. W. Stoughton, TID-5223, p. 126 (1952)

16) V. I. Kuznetsov, Zhur. Anal. Khim. 9, 199 (1954); Chem. Abst. 48, $13541 \mathrm{f}(1954)$.

17) V. I. Kuznetsov, V. N. Obozhin, E. S. Pal'shin, Zhur. Anal. Khim. 10, 32 (1955); Chem. Abst. 49, 8037 h (1955).

18) V. I. Kuznetsov, Sessiya Akad. Nauk S. S. S.R. po Mirnomu Ispolkovaniyu Atomnoi Energii 1935; Zasedaniya Otdel. Khim. Nauk. 301; Chem. Abst. 50, $111 \mathrm{~g}$ (1956).

19) V. I. Kuznetsov, G. V. Myasoedova, Zhur. Anal. Khim. 10, 211 (1955); Chem. Abst. 50, 107 b (1956)

20) V. I. Kuznetsov, L. I. Papnshina, Zhur. Anal. Khim. 11, 686 (1956); Chem. Abst. \$1, 7945 e (1957).

21) V. I. Kuznetsov, A. A. Akimova, Zhur. Anal. Khim. 13, 79 (1958); Chem. Abst. 52, 9863 h (1958).

22) I. E. Starik, A. P. Ratner, M. S. Pasrik, L. D. Sheidina, $J$ Anal. Chem. U.S. S. R. 12, 85 (1957).
出法を検討し，表 1 に示すような操作で分離精製したものをもち いた。試料には金属トリウムを原子灯 JRR-1 で 1 週間照射した ものをもちいた*2。最後にえられたプロトアクチニウム-233 無 担体溶液について， $\gamma$ 線スペクトルを観測したところ图1に示す ような結果がえられ，プロトアクチニウム以外の核種は諗められ なかった。なお，標準線源には水銀-203 の溶液をもちいた。

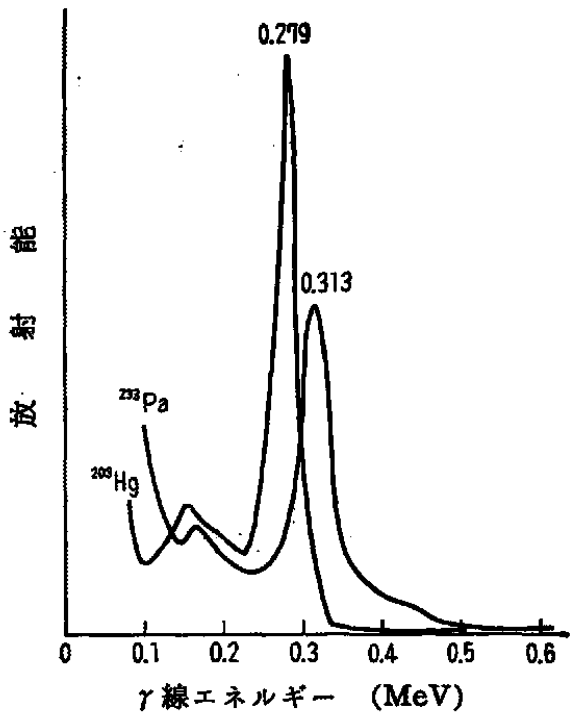

${ }^{288} \mathrm{~Pa}$ スペクトル (900 volt, Gain 8, range 1000) ${ }^{203} \mathrm{Hg}$ スペクトル (900 volt, Gain 8, range 300 )

図1プロトアクチニゥム -233 の

\section{2 いろいろの無機沈没へのプロトアクチニウム-233 の共沈} 前記のように二酸化マンガンへのプロトアクチニウムの共沈事 はきわめて高く，分離法として有効な手段であるが，他の無鈜沈 殿への共沈について検討した。

ビーカーに鉱酸 $10 \mathrm{ml}$, 担体溶液 $1 \mathrm{ml}$ (大体 $10 \mathrm{mg}$ ), プロト アクチニウムの溶液 $1 \mathrm{~m} l$ をとり，それに所定の系の沈段靔加 え沈殷を生成させる。30 分加熱，30 分放泠したのち，连心命離 (20分)を行ない，沈殿と溶液部をわける。沈段を溶解し，一定 量として $\gamma$ 線を眮定する*る。液については，これも一定量とし $\tau \gamma$ 線を測定する。探取時の放射能と各部分の放射能との比から 共沈紊を算出した。

結果を表示すると表 2 のとおりである。リン酸ジルコニウム, リン酸チタニウム，酸化チタニウムに対しては 90〜100\%プロト アクチニウムが共沈するが, 後処理の簡単な沈殿ではプロトアク チニウムはほとんど共沈しない。結扁，二酸化マンガン以外では 分離の目的に不適当と思われる。

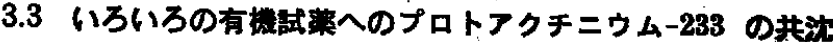

3.2 の実験結果からかかるように，鿏機共沈による分錐法はい ろいろ難点む多い。そこで有機共沈法によるプロトアクチニウ ムー233の分離について険討を試みた。

沈即試楽としては一般の有機試薬のうち，なるべく強酸性で重 金属と錯体を形成するようなもの，とくにトリウム，ジルコニウ ムと反応しそうなもののなかから，つぎのようなるのを選んだ。

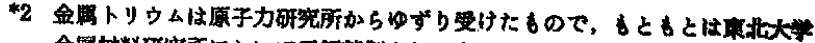

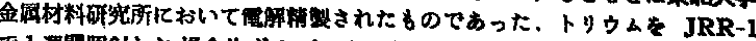

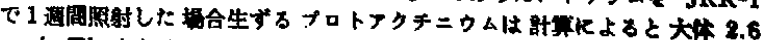
$\mathrm{mc} / \mathrm{g}$ Th となる。

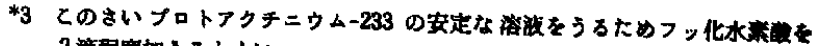
2 济程度如えるとよい。 


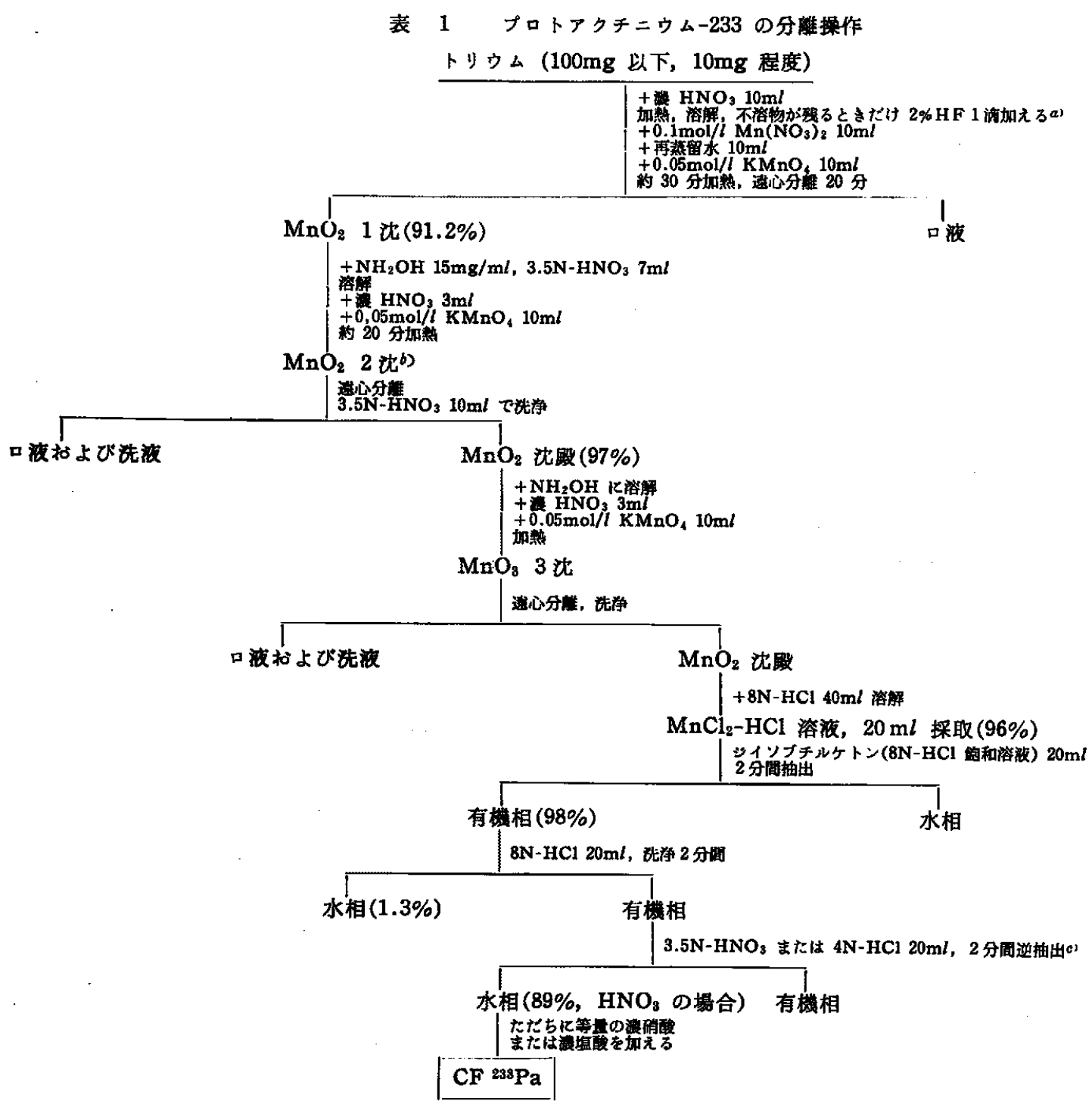

社 各操作でのカッコの数值仿収韧を示す。

a) (i ) Th $89.3 \mathrm{mg}$, 全容 $40 \mathrm{ml}, \mathrm{HF} 2$ 滴, $\mathrm{Mn}\left(\mathrm{NO}_{3}\right)_{2}, \mathrm{KMnO}_{4}$ 各 $1 \mathrm{ml}\left(\mathrm{MnO}_{2} 0.3 \mathrm{mg} / \mathrm{ml}\right)$ の場合, 1 沈 $\mathrm{MnO}_{2}$ 部 分 $67 \%$ ，口液 $10 \%$ ，洗浄花 $2 \%$ ，提失 $21 \%$.

(ii) Th $97.0 \mathrm{mg}$, 全容 $40 \mathrm{ml}, \mathrm{HF} 1$ 滴, $\mathrm{Mn}\left(\mathrm{NO}_{3}\right)_{2}, \mathrm{KMnO}$ 各 $10 \mathrm{ml}\left(\mathrm{MnO}_{2} 3 \mathrm{mg} / \mathrm{ml}\right)$ の場合, 1 沈 $\mathrm{MnO}_{2}$ 部分 $91.2 \%$ ，唯 $8.6 \%$ ，損失 $0.2 \%$.

(iii) $\mathrm{Th}$ なし, $\mathrm{HF} 2$ 滴, 他は (ii) と同し， 1 沈 $\mathrm{MnO}_{2}$ 部分 $77 \%$.

(iv) Thなし, $\mathrm{HF}$ な, 他は (ii) と同じ, 1 沈 $\mathrm{MnO}_{2}$ 部分 $97.5 \%$.

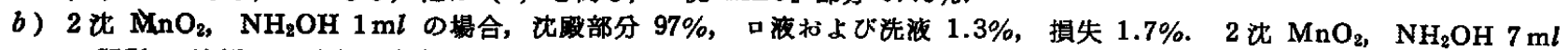
で $\mathrm{HCl}$ に溶解した場合, 共沈率 $96 \%$. したがって 2, 3 沈 $\mathrm{MnO}_{2}$ 部には ${ }^{233} \mathrm{~Pa} 96 \sim 97 \%$ 共沈する。

c）シインフテルケトン $8 \mathrm{~N}-\mathrm{HCl}$ での抽出率は $98 \%, 3.5 \mathrm{~N}-\mathrm{HNO}_{3}$ 等量での逆抽出率は $5 \mathrm{ml} 82 \%, 10 \mathrm{ml} 89 \%, 4 \mathrm{~N}-\mathrm{HCl}$ $5 \mathrm{ml}$ て $93.5 \%$ となった.

すなわち，N-ベンゾイルフェニルヒドロキシルアミン， $\alpha$-ニト ロソー $\beta$-ナフトール, キサントゲン酸カリウム, ヘキサメチレン テトラそン, $p$-ヒドロキシフェニルアルソン酸ナトリウム, テ トラフェニルアルソン酸の6 種である。そして，これらの試薬自 身を沈殿させた場合, およびこれらの試薬により担体を沈殿させ た場合のプロトアクチニウムの共沈を検討した。

$1 \mathrm{~N}$ 塩酸 $10 \mathrm{ml}$ にプロトアクチニウム $1 \mathrm{~m} l(8 \mathrm{~N}$ 塩酸酸性)を とり,これに適当な担体を加える。つぎに有機試薬の水溶液 $5 \mathrm{ml}$ を加え，30分放置したのち，遠心分離（20分）を行なう。沈殿を 溶解し，一定量として放射能を測定する。口液の部分について屯 一定量とし, 放射能を測定する。採取時の放射能との比から共沈 率を算出する。また，水に不溶性の有機試薬ではこれらの有機試
薬のアルコール溶液をむちいる。この場合にはアルコールを蒸発 させれば試楽の沈殿がおこるから，担体を加えない場合でもこう して生ずる試薬自身との共沈が期待できる。よってこれらの試薬 の場合には担体を加えて試藥により沈殿させた場合と上記のよう な詶梁だけの沈殷との共沈率を求めた。 $N$-ベンゾィルフェニル ヒドロキシルアミン， $\alpha$-ニトロソー $\beta$-ナフトール， $p$-ヒドロキ シフェニルアルソン酸ナトリウム, テトラフェニルアルソン酸の 場合にはジルコニウムを, キサントゲン酸カリウムではモリブデ ン, ヘキサメチレンテトラミンではトリウムを担体にもちいた。

これらの試薬へのプロトアクチニウムの共沈結果は表 3 に示す とおりである。なお，テトラフェニルアルソン酸は壏酸酸性にお いてジルコニウムを担体とした場合，沈殿しなかった。 


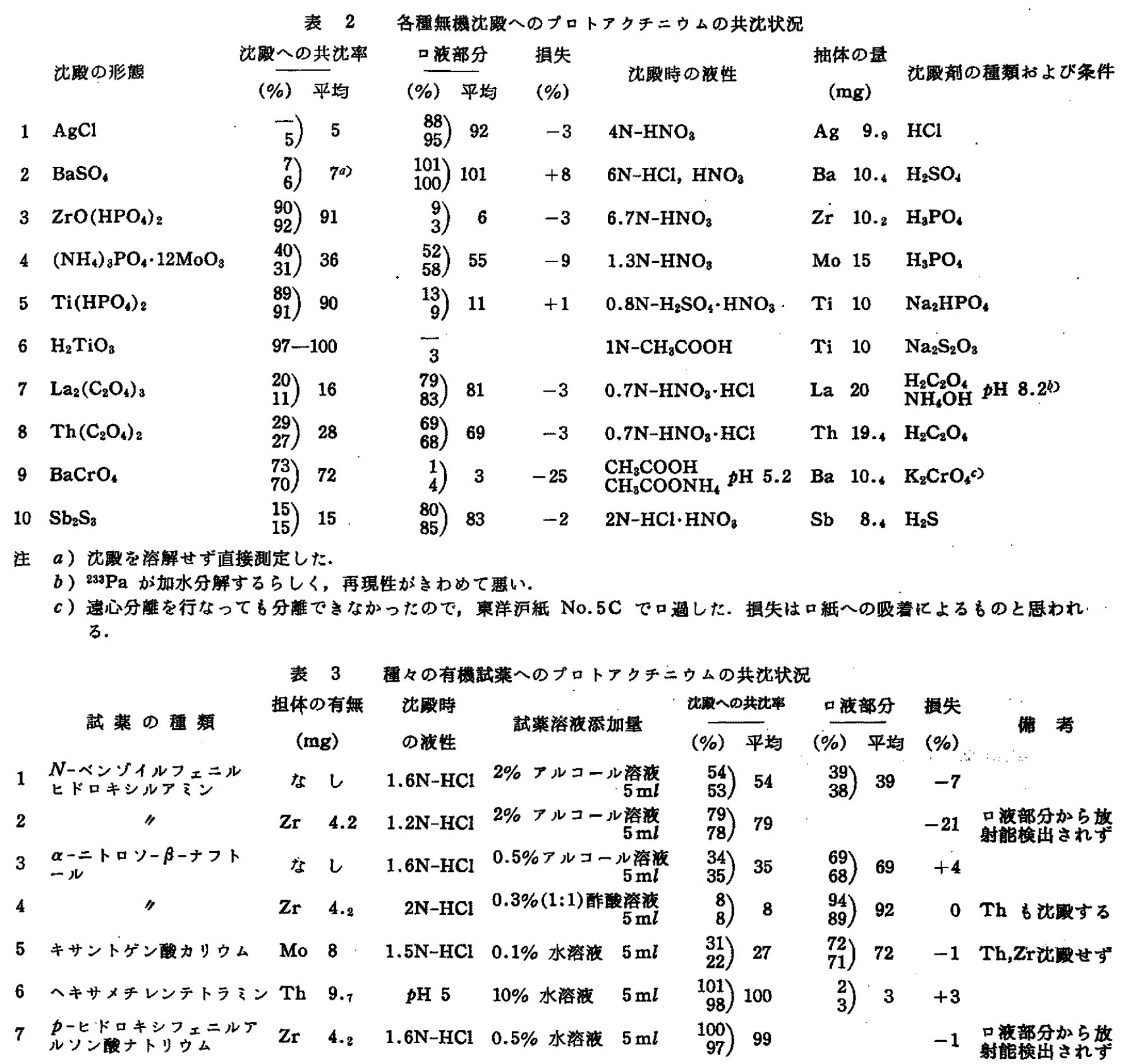

表 3 からプロトアクチニウムの共沈棛として, $p$ ーヒドロオキシ フェニルアルソン酸ナトリウムと $N$-ベンゾイルフェニルヒドロ キシルアミンがもっとも有効のように思われる。なお, ジルコニ ウムは強酸性溶液から $N$-ベンゾイルフェニルヒドロキシルアる ンにより沈殿するが, トリウムは沈殿せず，10\%酶酸アンモニウ 么溶液 $p \mathrm{H} 5.0$ において沈殿を生じた ${ }^{23224) 。 ~}$

$3.4 N$-ベンゾイルフェニルヒドロキシルアミンによるプロト アクチニウム-233 の共沈分離法の検討

3.3 の実呀からプロトアクチニウムはジルコニウム担体で $p$ ヒドロキシフェニルアルソン酸ナトリウム, $N$-ベンゾイルフェニ ルヒドロキシルアミンによりきわめてよく捕集されることがわか った。しかし，この場合にはジルコニウムとの分離が後処理とし て問題になってくる*。。そこで後処理に問題の少ない $N$-ベンゾ

23) S. K. Sinha, S. C. Shome, Anal. Chim. Acta. 21, 415 (1959).

24) I. P. Alimarin, Tze Yung-Schaing, I, 317 (1961).

*4 相体にシルコニウムを用い, $N$-ベンゾイルフニニルヒドロキシルアミンを

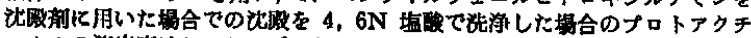

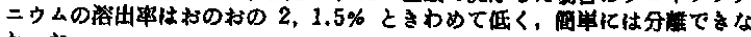
加た.
イルフェニルヒドロキシルアミンのみを訧殿骩にもちいた場合に ついて詳細に検討した。

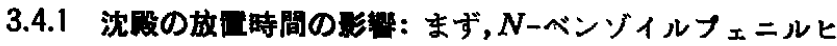
ドロキシルアミンで沈殿を行なうときの, 沈殿の放置時間の影珵 を検討した。

$1 \mathrm{~N}$ 塩酸 $10 \mathrm{ml}$ およびプロトアクチニウム $-2331 \mathrm{ml}$ (8N 塭 酸酸性)をとり，これに $N$-ベンゾイルフェニルヒドロキシルア ミン $0.1 \mathrm{~g} 5 \mathrm{ml}$ のエチルアルコールに溶かした液を加える。 溶液を 30 分間赤外線ランプで加熱（温度 $70^{\circ} \mathrm{C}$ ）したのち，い ろいろの洔問, 沈殿を放置し, 遠心分離(3000 回転/分, 20 分)を 行なう。沈殿および溶液部分についてそれぞれ放射能を測定し， 探取時の放射能との比から共沛率を求めた。

結果は表 4のとおりである。表からかかるように，放置時間を 大にしても共沈苏に大きな变化はみられなかった。

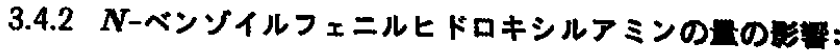
$N$-ベンゾィルフェニルヒドロキシルアミン $0.1,0.2 \mathrm{~g}$ むいた 場合の共沈率を検討した。操作は 3.4 .1 と同様である。結果は表 
表 4 プロトアクチニゥム-233 の共炕に対する 沈殿の放目時䦩の影辨

\begin{tabular}{|c|c|c|c|c|c|}
\hline \multirow{2}{*}{ 放置 時 間 } & \multicolumn{2}{|c|}{ 沈䃘への共沈率 } & \multicolumn{2}{|c|}{ 口液部分 } & \multirow{2}{*}{$\begin{array}{l}\text { 撌失 } \\
(\%)\end{array}$} \\
\hline & $(\%)$ & 平均 & $(\%)$ & 平均 & \\
\hline 1 時間20分 & $\begin{array}{l}77 \\
75\end{array}$ & 76 & $\begin{array}{l}19 \\
22\end{array}$ & 21 & -3 \\
\hline 3 時 間 & $\begin{array}{l}72 \\
74\end{array}$ & 73 & $\begin{array}{l}26 \\
22\end{array}$ & 24 & -3 \\
\hline 21時間30分 & 75 & & 18 & & -7 \\
\hline
\end{tabular}

表 5 プロトアクチニウム -233 の共沈に対する $N$-ベンソ イルフェニルヒドロキシルアミンの量の影繁

試莱の量 放屡特間 沈即への共沈率 口花部分

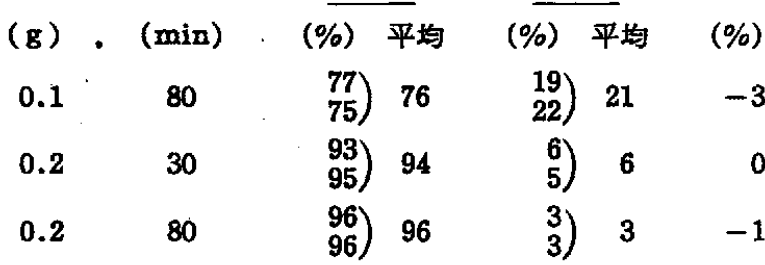

5 に示すとおりである。

$0.2 \mathrm{~g}$ あちいるとプロトアクチニウムは 96\% 共沈尗る。また， 放置時間を 30 分にした場合には 94\% のプロトアクチニウムが 共沈した。 $N$-ベンソイルフェニルヒドロキシルアミンの溶媒と してアルコール以外にジオキン， メチルセルソルブ，アセトン の使用も考えられるが,これらは溶解度，沸点などに問題があり， 溶媒としてアルコールがあっとも適当と思われる。

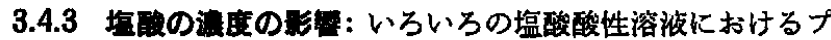
ロトアクチニウムの共沈状沇を検討した。操作は 3.4.1 と同様で あるが。 $N$-ベンゾイルフェニルヒドロキシルアミンは $0.2 \mathrm{~g}$ あちいた。結果は表 6 のとおりである。

表 6 プロトアクチニウム-233 の共沈に対する

\section{塩酸の浀度の影帮}

\begin{tabular}{|c|c|c|c|c|c|}
\hline 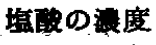 & 沈段へ0 & 共沈率 & 口湾 & 部分 & 損失 \\
\hline (N) & $(\%)$ & 平均 & $(\%)$ & 平均 & $(\%)$ \\
\hline 0.7 & $\left.\begin{array}{l}94 \\
94\end{array}\right)$ & 94 & $\left.\begin{array}{l}7 \\
6\end{array}\right)$ & 7 & 1 \\
\hline 1.6 & $\left.\begin{array}{l}96 \\
96\end{array}\right)$ & 96 & $\left.\begin{array}{l}3 \\
3\end{array}\right)$ & 3 & - \\
\hline 2 & $\left.\begin{array}{l}101 \\
101\end{array}\right)$ & 101 & & & \\
\hline 4. & $\left.\begin{array}{r}96 \\
101\end{array}\right)$ & 98 & & & \\
\hline 6 & $\left.\begin{array}{l}36 \\
28\end{array}\right)$ & 32 & $\left.\begin{array}{l}64 \\
70\end{array}\right)$ & 67 & \\
\hline
\end{tabular}

塭酸の浱度が低いところでは共沈率が若干減少する。それはプ ロトアクチニウムが加水分解などを起すためと思われる。塩酸の 搌度が大になると $N$-ベンゾイルフェニルヒドロキシルアミンが 沈段しなくなり，共沈率も減少する。結局，2N 塩酸酸性程度が 哏良と思われる。

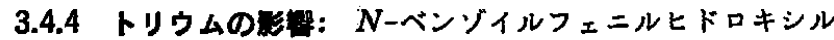
ア マン人のトリゥムの沈殿については 3.3 においてすでに定性的 に検䣓し，0.5N 塭酸酸性以上では沈殿しないことを確かめてい

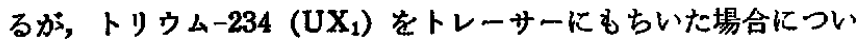
て検討した。なお，トリウム-234 は硝酸ウラニルからクッペロ ン法により分離したものをむちいた ${ }^{25) 。 ~}$

25) E. K. Hyde, NAS-NS-3004, p. 51 (1960).
トリウム 234 拉びトリウム担体を含さ $1.6 \mathrm{~N}$ 塭酸酸性溶液 について， $N$-ベンゾイルフェニルヒドロキシルアミンによる炏 殿反心忘試みた。操作注 3.4.3 のとおりであり，表 7 に示与よう な絬果がえられた。この結果からトリウムはほとんど踑沈しない ことがわが*5。

表 7 トリウムの影響

$\begin{array}{ccc}\begin{array}{c}\text { リウムの含有量 } \\ (\mathrm{mg} / \mathrm{m} l)\end{array} & \text { 沈段へのトリウムの共沈率 } & \begin{array}{c}\text { 口液の部分 } \\ (\%)\end{array} \\ 13 & 3 & 97 \\ 8 & 3 & 97\end{array}$

注㕪䖉は希㙁酸で 1 回洗浄した.

3.4.5 硝酸の䅆望: プロトアクチニウムの共沈に対する硝酸の 影腊および硝酸の分解削として尿素およびヒドロキシルア ミンを 加えた場合について検討した。

$1 \mathrm{~N}$ あるいは $2 \mathrm{~N}$ 硝酸で N-ベンゾイルフェニルヒドロキシル アミンの沈殿を生成させ; プロトアクチニウムの共沈率を酷べた。 また，硝酸溶液に $5 \mathrm{~mol} / l$ 尿素あるいは $5 \mathrm{~mol} / l$ ヒドロキシ ルアミンを加え, 溶液を加熱沸とうしたのち, $N$-ベンゾィルフェ ニルヒドロキシルアミンの沈股を生成させた場合について笑験を 試みた。

操作は 3.4 .3 と同様であり，結果は表 8 に示すとうりである。 表 8 からかかるように $1 \mathrm{~N}$ 硝酸酸性までは共沈动に 影背がない

表 8 プロトアクチニウム -233 の共沈に対する硝酸の影犁

反 応策件 沈殿への共比率口液部分損失

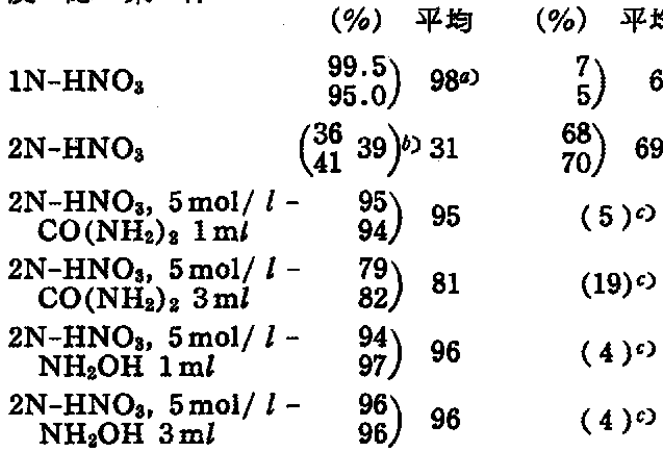

注 a) $1 \mathrm{~N}-\mathrm{HNO}_{3}$ の㘿合も一部酸化され少医ながら不浴物が できた.

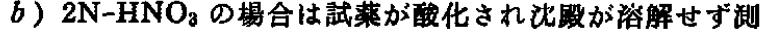
定管の底に沈殷したままであるため，测定值は大とな った.

c）品の部分について湖定は行なわなかった．したがっ て，口液部分にくると推定される值である.

が，2N 硝酸酸性になると $N$-ベンゾィルフェニルヒドロキシル アミンが酸化され，共沈率はいちじるしく低下する。また，硝酸 の分解戍として㽷䋕よりヒドロキシルアミンの使用がより有奻と いえよう。

3.4.6フッ素イオンの影刯：プロトアクチニウム -233 の共沈 に対するフッ素イオンの影翣について検討した。結果法 9 のと おりである。

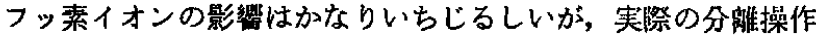
においては濃硝酸のみでほぼ完全に試料を溶艧できるから，あま

*5 ウラン, 希土制についてる検郡したが，いずれもプロトアクチニウムの共谈 条件である $2 \mathrm{~N}$ 埧酸酸牲では $N$-ヘンソイルフェニルヒドロキシルアミンと 共叱しなかった。 
表 9 プロトアクチニウム -233 の共沈に対する フッ䋕イオンの影榔

フッ化水素酸の付加量

\begin{tabular}{cc}
\hline$\%)$ & 平均 \\
32 & \\
$33)$ & 33 \\
17 & \\
$15)$ & 16 \\
12 & \\
11 & 12 \\
30 \\
$47)$ & 39
\end{tabular}

口液部分

損失

$2 \% \mathrm{HF} 1$ 滴

(\%) 平均

$2 \% \mathrm{HF} 2$ 擜

67) 67

78) 81

0

$0.5 \mathrm{~N}-\mathrm{HF}$

$2 \% \mathrm{HF} 1$ 滴, $0.1 \mathrm{~mol} / l-$

$\mathrm{H}_{3} \mathrm{BO}_{3} 1 \mathrm{ml}$

47) 39

83) $84-4$

55) $60-1$

り問題にならない。

$3.5 N$-ベンソイイルフェニルヒドロキシルアミンによるトリウ ム中のプロトアクチニゥム-233 の共沈舟蓶

以上の検討から $N$-ベンゾイルフェニルヒドロキシルアミン単 独でプロトアクチニウム-233 を共沈分踓するのに適当な 条件を 知ることができた。そこで，実際にこの方法によりトりウムの中 性子照射試料よりプロトアクチニウムの共沈分離を行なった。操 作は表 10 に示すとおりである。本操作によるプロトアクチニウ 么の回収率は 2 回の実鈋から 93，97\% ときわめて良好な結果が えられた。また, プロトアクチニウム-233 の最終溶液の $\gamma$ 線ス ペクトルを観測したところ図 1 と同様のスペクトルがえられ，放 射化学的にきわめて純粋であることを確認した。

表 $10 N$-ペンゾイルフェニルヒドロキシルア テンによる ${ }^{233} \mathrm{~Pa}$ の分離操作

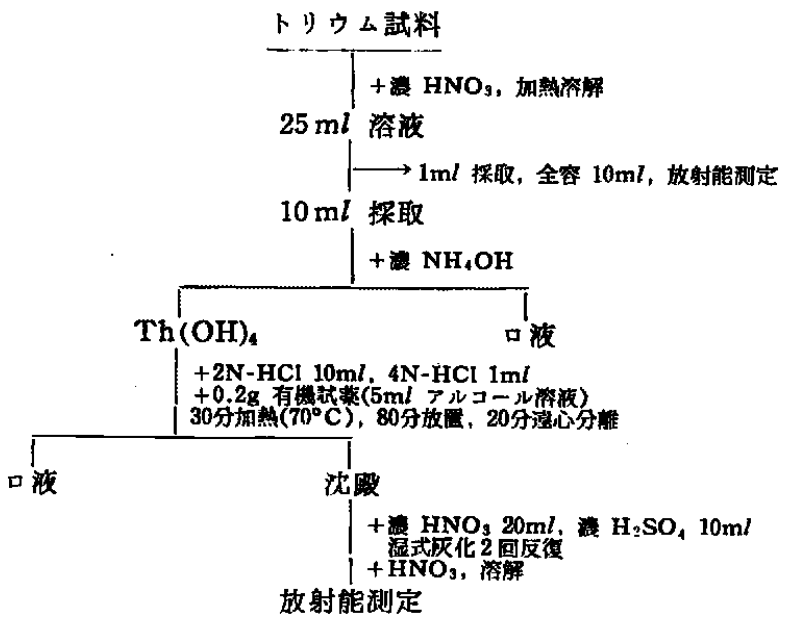

\section{4 考。察}

以上の実験結果から $N$-ベンゾイルフェニルヒドロキシルアミ ンによるプロトアクチニウムの共沈分嚾法としてつぎのち法が確 立される。

1）トリウムを濃硝酸に溶解し，2N 程度に希釈する。ヒド口 キシルアミンを加えて，硝酸を分㑇する*。

2) 適当量の垍酸を加えて，2N 塩酸酸性とし，溶液 $10 \mathrm{ml}$ に 対し， $N$-ベンゾイルフェニルヒドロキシルアミン $0.2 \mathrm{~g}$ を含む アルコール溶液 $5 \mathrm{ml}$ を加え, $70^{\circ} \mathrm{C}$ で 30 分間加熱, 80 分放冷 したのち, 20 分练心分離を行なう*7。

3）沈殿を硫硝酸または硝酸過熄素酸で湿式灰化し，プロトア クチニウム -233 無担体湲液をうる*8。

以上述べたように本法は従来法と異なり，有機咓薬を加えるこ とにより，1 回の操作で簡単にプロトアクチニウム-233 を無担 体状態で共沈分離することができる。しかも，本法によれば当然 問題となるトリウム，希土類，ウランなどの共沈はさきに述べた とおり，ほとえど共沈しないから，一般の共沈分踓法にくらべ， きわめてすぐれた方法と思われる。

本実験の結果から $N$-ベンゾィルフェニルヒドロキシルアミン はジルコニゥムの共沈棛, プロトアクチニウムの抽出靔としてむ きわめて有効と考えられるが，これらについてい目下検䒬中であ る。また, $p$ ーヒドロキシフェニルアルソン酸ジルコニウムにプ ロトアクチニウムがよく共沈することはさきに述べたとおりであ るが, その詳細についても検討中である。

最後に本実魵觉行なうにあたり種々御指尊下さった東北大学理

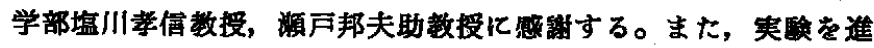

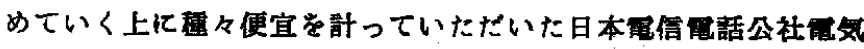
通信研究所一宮虎雄茨城支所長, 永井省三研究室長に心加ら御礼 申し上げる。

(1961 年 10 月, 第 5 回放射化学討論会講演)

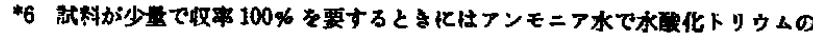

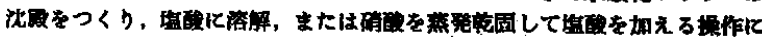
する。

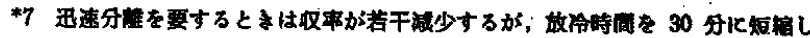

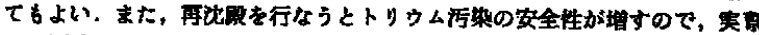
には再沈腶を行なった方がよい，

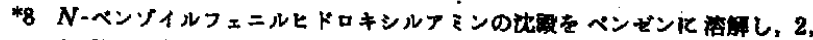

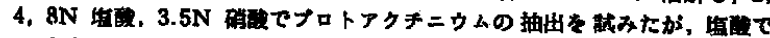

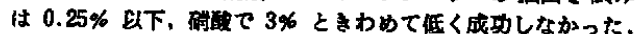

\section{アリールアデマロンアルテヒドの合成*1}

(昭和 36 年 5 月 31 日受理)

增尾富士雄・木 村善男十

1,1,3,3-テトラメトキシプロパンの加水分解によって得られるマロンアルデヒド( $\beta$-オキシアクロレイン) は, 程々の若香族ジ

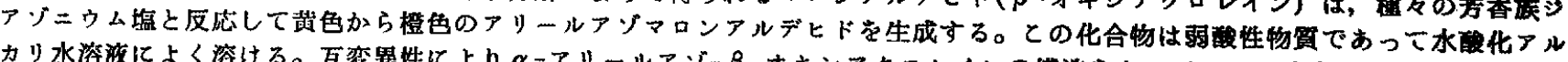

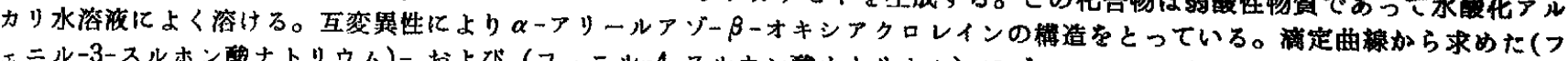

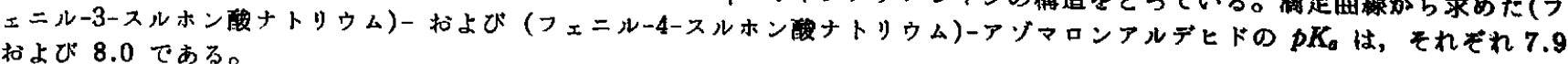

